\title{
The Value of Adult and Community Education and Training to the Empowerment of Rural Women in South Africa
}

\author{
Sampson Tawiah*, Zamalotshwa Thusi-Sefatsa \\ School of Education, Faculty of Arts \& Design, Durban University of Technology, South Africa
}

Received August 1, 2021; Revised September 18, 2021; Accepted October 17, 2021

\section{Cite This Paper in the following Citation Styles}

(a): [1] Sampson Tawiah, Zamalotshwa Thusi-Sefatsa, "The Value of Adult and Community Education and Training to the Empowerment of Rural Women in South Africa," Universal Journal of Educational Research, Vol. 10, No. 1, pp. 14 21, 2022. DOI: 10.13189/ujer.2022.100102.

(b): Sampson Tawiah, Zamalotshwa Thusi-Sefatsa (2022). The Value of Adult and Community Education and Training to the Empowerment of Rural Women in South Africa. Universal Journal of Educational Research, 10(1), 14 - 21. DOI: 10.13189/ujer.2022.100102.

Copyright $\bigcirc 2022$ by authors, all rights reserved. Authors agree that this article remains permanently open access under the terms of the Creative Commons Attribution License 4.0 International License

\begin{abstract}
The imbalances of the South African education system before 1994 resulted in many rural women predominantly without education and training. The lack of primary education and skills has beckoned many women to ill-treatment, rejection, vulnerability, abuse, hunger, diseases, poverty, and unemployment. For women to thrive socially and economically, education is crucial. So Adult and Community Education and Training (ACET) for the underprivileged rural women are essential for development and empowerment today. The overarching aim of ACET is to empower rural women with knowledge and livelihood skills to tackle their socio-economic problems. The study, therefore, aimed to explore the significance of ACET on the socio-economic lives of women, especially those in rural areas. The researchers conducted qualitative interviews with 35 women who were purposively selected for the study and deemed information-rich. The study's findings indicated a lack of skills training programs to empower women and a lack of access to ACET programs. Therefore, the paper recommends that ACET programs be structured to meet the learning needs of women.
\end{abstract}

Keywords Adult and Community Education and Training, Empowerment, Livelihood, Women, Socio-Economic Development

\section{Introduction}

Conditions of the past political era during apartheid before South Africa became a democratic state in 1994 were the cause of many South African citizens, particularly women, without primary education [22]. Lacking education resulted in abuse, vulnerability, melancholy, marginalization, and poverty. However, in contemporary democratic South Africa, black South African citizens, especially women, have the opportunity to be educated to improve their welfare. Indeed, education can help individuals uplift their living conditions, which is why Adult and Community Education and Training (ACET) [9] for women in rural areas, in general, become an essential developmental tool. The principal aim of ACET is to provide rural women with knowledge and livelihood skills to tackle socio-economic problems like gender inequality, vulnerability, abuse, hunger, diseases, unemployment, and predominantly poverty. As Baatjes and Chaka [1] affirm, ACET is an empowerment program for the poor who do not have educational training. Through the Department of Higher Education and Training (DHET), the South African government aims to empower millions of its citizens in rural areas with livelihood skills to combat poverty. Hence, it has established Adult and Community Education and Training (ACET) [9] nationally. However, as observed by the author, many women rural dwellers, in particular, are not 
participating in the empowerment programs of ACET because the programs do not fulfill their needs. This article, therefore, argues for the complete liberation of women through development in skills.

In general, the provision of adult education programs to enable the poor is a significant plight of most progressive leaders in countries around the globe. Griggs et al. [14] uphold that adult education programs allow governments worldwide to empower women, especially to fight insufficiency, starvation, and disease, to promote advancement in economic undertakings. ACET is a crucial developmental agenda in South Africa to emancipate rural women. The researchers contend that successful women provide for their family's survival needs in the country's complex commercial system. Hence, they need practical livelihood skills. Unfortunately, ancient practices have rendered ACET programs unfulfilling to women, thus resulting in persistent poverty and a high unemployment rate.

Training in skills is a state-of-the-art gizmo to help rural women fight ostracism, joblessness, and poverty. These are towards the emancipation of women [27]. The authors intimate that the role women play is critical in the family. Therefore, without helping them attain industrious skills, they will not be able to get involved in economic activities, which will help them care for the whole family. Thus, ACET institutes should ensure that their packages are hands-on towards answering the needs of women. This article accentuates the relevance of ACET in the lives of rural women. The institute aims to tutor and up-skill the deprived women and gets them ready to engage in economically focused activities to allow and contribute to both community and nation's development.

\section{A Brief History of Adult Education in South Africa}

The coming of the apartheid government in 1948 contributed significantly to the low literacy level in South African societies. The form of education that the apartheid government provided made the blacks hopeless in their quest for an equitable society and inclusiveness. The apartheid government appointed a commission to disadvantage the blacks educationally. Hence, the commission formulates the values and goals of education for Natives (black citizens) as a segregated race [30]. This commission recommended the Bantu Education Act of 1953 as a foundation for the formulation of legislation. It designed the Act to educate Africans to conform to their wishes. In this regard, the education proposed for the blacks rendered them inferior and perpetually living in servitude [30]. Besides, apartheid education teaches blacks conformity, loyalty to superiors, divisions in ethnicity, not deviating social roles, and to be identified with a particular rural culture. Affirming this, the Minister of Native Affairs emphasized that the black child has no place among their white folks. Black citizens were subjects of a school system that alienated them from their communities. The white communities were not grazing land for blacks [30].

However, to start driving education in Africa, especially South Africa, the missionaries were the first to promote educational activities. The aim is to make a literate society. For example, the different ethnic groups in the country began their education through the help of missionaries [18]. In missionary schools, the primary education given was Literacy education (reading and writing). Missionary families were responsible for teaching the blacks reading and writing. Literacy in black communities was possible owing to missionaries' contributions.

Nevertheless, the black communities had huge populations that needed literacy post-1994. Hence, well-wishers in the political landscape, religious organizations, and non-governmental organizations (NGOs) contributed to the education of the blacks by establishing schools that were run only on a nightly basis. It was the only means to make a literate community of the natives. However, these night schools did not survive because colonial masters refused to support the program [15] financially.

Post-apartheid government after democracy encountered several challenges. Some of the obstacles included the following:

1) There were very high numbers of adult citizens functionally illiterate;

2) Many adult citizens were unemployable because of illiteracy;

3) Many black citizens lack entrepreneur skills in the formal and informal regions; and

4) Increased poverty levels owing to a lack of economic and productive skills.

With a vision to improve illiteracy in the country and afford better living conditions for all South Africans, the African National Congress (ANC) inaugurated a policy on Reconstruction and Development [3]. The procedure was significant to community development, premising its values into skills training for enhancing growth. Adult Basic Education and Training (ABET) was a mandate that drove this progressive socio-economic schema in South Africa. Nonetheless, the program of ABET did not see any progress because it failed the needy who require job skills for leverage [1]. The failure of ABET is the result of the adoption of Adult and Community Education and Training $[9,10]$ in the country today.

Indeed, South Africa has seen many school dropouts of youth and adults, particularly womenfolk, in rural regions [9]. Because of this condition, ACET has gained currency nationally in the country. It aims to alleviate dependency on others for basic human needs through skills acquisition and knowledge to lead rewarding lives. Consequently, this 
study examined the central question: What contributions have Adult and Community Education and Training made towards women's liberation in underdeveloped communities?

\section{Objective of the Study}

The researchers stated the following objectives for the study to;

- Find out whether women get the needed training to lead valuable lives;

- Find out whether the women are involved when designing educational curriculum;

- Find out women access to ACET programs; and

- Affirm whether the location of ACET centers benefits women.

\section{Theoretical Framework}

The theory which underpins this study is the empowerment theory. The American psychologist Julian Rappaport developed the empowerment theory in 1981. Defining empowerment, she said thus;

Empowerment is a pervasive positive value to both individual determinations over one's own life and democratic participation in the life of one's community, often through mediating structures such as schools, neighborhoods, churches, and other voluntary organizations [28].

The words above indicate a process meant to access individuals' conditions and find solutions to such problems.

The empowerment theory compares to power and powerlessness [19]. Power is the ability of persons or establishments to alternate the statuses of others [23]. In other words, people's lives can be affected negatively or positively by others or organizations. On the other hand, powerlessness depicts the inability to affect others either positively or negatively. Ultimately, empowerment points to an enabling environment that allows people to change for the better. Lord and Hutchison [19] affirm that accessing empowering resources like wealth and prominent organizations demands abled individuals. The researchers argue that individuals can become powerless without access to empowerment resources like education, social, economic, and political. These features of empowerment are discussed briefly in the paragraphs below:

Social Empowerment: This developmental process helps individuals achieve respect, honor, and status in their communities. This form of empowerment encourages social cohesion and brings about gender-based equality [20].

Educational Empowerment: Education forms an integral part of empowering individuals. Educational empowerment, therefore, aims to educate individuals to develop their intellectual ability and welfare. Again, it seeks to increase the economic potential in individuals for participation in every economy to bridge the gender gap [17].

Economic Empowerment: this form of empowerment focuses on individuals' abilities and capacities to provide for their homes. Hence, individuals need to be educated and trained to wage employment and self-employment to achieve economic empowerment. According to Elliott [12], wage employment is economic power. This notion means that financially sound persons are in a better position to care for their homes. Hence, individuals must be education and skills training are crucial for participation in the economy of their immediate communities and the country at large.

Political Empowerment: Politically, when individuals have a say in decision-making, planning, and debates, they are considered empowered. Empowered persons can handle political matters, promoting gender-based equality among women and fostering leadership roles in political spheres [20].

Essential principles are embedded in the empowerment theory. Chamberlin and Schene [4] list out these principles to include the following:

- Partaking in decision-making;

- Able to access information and resources;

- There are several options for choices (not just

yes/no);

- Decisiveness;

- Able to impact others;

- The feeling of belongingness;

- Respecting the rights of others;

- The ability to influence others positively in communities;

- Changing the perceptions of one's competency and capacity to act.

Acquiring and practicing some of these principles (and not necessarily all) is essential to positively affect the empowerment theory on individuals.

\subsection{The Implications of the Empowerment Theory to the Study}

From the discussion above, the empowerment theory can have significant implications to benefit the study. Given that most women in deprived communities are uneducated and untrained, there is value in the empowerment theory as giving insight into women's education. Therefore, whatever schooling and training women receive must be towards their economic emancipation. Kamando [16] posits that the empowerment theory involves a social process that transforms individuals through practical knowledge and life skills for productivity. Hence, women can rethink their experiences and do what is necessary to change their lives [13]. 
Similarly, the theory has favorable consequences for women in rural areas. Application of the principles of the empowerment theory can benefit women. Hence, women must adopt its directions to enable ACET programs to transform them for better living conditions. Women should be optimistic, up-to-date through awareness, and exercise control of their lives.

The providers of Adult and Community Education and Training (ACET) programs can also benefit from the theory in that it speaks to their programs. ACET programs must empower the educationally disadvantaged in a broader spectrum with practical livelihood skills [10]. As the programs concern women, they must suggest and design the programs meant to empower them. According to O'Faircheallaigh [25], those desiring personal development must participate in developmental initiatives aiming at their empowerment. Indeed, rural women voice their opinions and ideas to ensure social cohesion and inclusiveness in society.

\section{Research Design and Methodology}

The researchers engaged a qualitative research approach to examine the socio-economic worth of ACET on women's lives in rural areas in the Mthatha district, South Africa.

\subsection{Research Design}

The researchers adopted an experimental design [6] to explore justice done to women in rural Mthatha, in South Africa, through the provision of ACET. They also assumed a phenomenological method to conduct interviews and data analysis processes. This method helped the researchers relate well with participants and better understand their lived experiences during the interviews. Correspondingly, the approach allowed the researchers to describe the participants vividly during the data analysis process $[32,5]$. Those involved in the research were adult female learners who have gone through ACET programs or enrolled in ACET programs and female educators. They were selected because women experience situations in their lives that they are rightly disposed to correct [31]. Interviews were in-depth and conducted face to face with participants for relevant information. The researchers identified suitable locations to conduct the interviews with participants. The researchers also made arrangements to interview participants telephonically as some were not available for a face-to-face interview (particularly some previous learners).

\subsection{Population and Sample}

The study sampled 35 women purposively since it spotlighted women only. This section of women is deemed apt and commended for a qualitative study [21]. The selection comprises 24 female students, seven former students, and four female educators. These participants were chosen since they were deemed information-rich. $\mathrm{He}$ used the following criteria for sampling the participants:

- Participants must register for the ACET program;

- Participants must have gone through the ACET program;

- Participants must be willing to participate in the study; and

- Participants must be well informed about ACET programs.

These criteria are justified because they elicited relevant information from the participants. In addition, the participants were knowledgeable about ACET programs.

\subsection{Ethical Consideration}

Research demands that ethics are adhered to throughout the study. One of research ethics is to respect the rights of all the participants. Affirming this, Creswell and Clark [7] indicate that respecting participants' rights, needs, and values should be a priority. Hence, the researchers respected participant's views and integrity. Again, they inform participants of how long the study will be and how much time the researchers need to interview participants. Before conducting the study, the researchers sought permission from adult education authorities and waited for feedback to conduct the study. The participants voluntarily signed consent forms to indicate their willingness to participate in the study. The participant's names were not used anywhere in the research study to ensure confidentiality and anonymity. Finally, the participants could withdraw from the study at any time they feel like doing so.

\subsection{Data Collection}

The main instruments for collecting data were interviews and focus group discussions. The researchers sought permission from the center supervisors to access participants' cell phone numbers. They made arrangements with participants to conduct face-to-face interviews and focus group discussions. Because of peculiar reasons, some participants were unavailable for face-to-face interviews. Hence, the researchers made arrangements to conduct the interviews telephonically, particularly with previous students who have left to seek greener pastures. From the sample size of 35 participants, four members engaged in a focus group discussion. The researchers selected four members purposively from four different adult learning centers in the Mthatha District. The participants were chosen from various centers to help them avoid peer intimidation and solicit ideas and views. In addition, the researchers also interviewed four educators nominated from different learning centers. Their 
responses triangulated the responses from the other participants.

\subsection{Data Analysis}

After collecting data from the participants, the researchers analyzed the data manually. The researchers transcribed the interviews into text. It allowed them to read and expand on the information gathered [24]. Discussion and field notes helped the researchers understand the collected data during the interview process and focus group. They interpreted, analyzed, and gave codes to the data; arranged them under various themes and categories that addressed the research questions and objectives [2]. Finally, the researchers presented the emergent findings based on the analysis of the data collected. The participant's voices were evidence of the results explained. Thus, the authors sequentially presented events as a thorough discussion of numerous subjects and others linked to the study's outcomes [8].

\section{Findings and Discussion}

This study investigated women's liberation in underdeveloped communities through Adult and Community Education and Training in the Mthatha area. The study's findings are presented and discussed below.

\subsection{Lack of Skills Training Programs to Empower Women in Rural Areas}

Because many women in rural areas are without access to primary education and training owing to the ill conditions of the past colonial government, South Africa used her democratic freedom as a gateway for women to have rights and opportunities to education and training for empowerment. Hence, the advent of Adult and Community Education and Training (ACET) is timely for the development of women, especially in rural communities [9]. ACET aims to run programs such as bead-making, cloth weaving, basket weaving, computer skills, Agriculture, carpentry, dressmaking, plumbing, painting, electrical works, and pottery. These practical skills can empower women with economic skills for self-employment and improve their living conditions. However, satellite community learning centers that ensure the implementation of ACET programs have failed to provide such programs for their students. Yet, the mandate of ACET is to give these livelihood skills, but unfortunately, it has been unable to do so. One of the participants affirmed thus;

The ACET centers have no empowerment programs like leather works, fashion design, or plumbing that we need for our training to engage in work activities. We only learn subjects such as Isixhosa, English, and Basic Early Childhood Development which cannot help us to engage in our business activities to generate income for livelihood.

Another participant also affirmed by saying that; I am a learner in the ACET program. I am studying subjects such as Life Orientation, English, Xhosa, Ancillary, ECD, and Maths Literacy. I do not think the program is empowering me with the skills I need.

Family heads have a responsibility to care for the physical needs of their households. Women who are single parents are heads of their families, so they have enrolled in ACET programs to be skilled and helpful to themselves and those of their own. Therefore, skills training should be paramount in their education as this is the means for emancipation from economic difficulties to encourage commercial participation. Because women lack in skills to engage in profitable businesses, they are marginalized, discouraged, unemployed, and live in poverty. The literature study of the current research has revealed that to free women from economic dejections, they need to be trained and knowledgeable [27]. Skill training is essential to empower rural women; however, its neglect in education hampers their development. The study revealed that this situation is evident in ACET learning centers due to ancient educational practices and the lack of proper management and implementation of ACET policies. Dreze and Sen [11] affirm that skill training is lacking in the education of rural women because of over-dependence on welfare. Singh [29] averred that liberating rural women from socio-economic enslavement are possible through skills training. However, neglect of life skills in their training due to a lack of educational policies renders them powerless and impoverished. A respondent affirmed this state by lamenting that;

There are no empowerment programs such as leather works, sewing, or plumbing that we receive at the center. We are only increasing our knowledge of the subjects we are learning at the center to receive a certificate at the end of our studies.

The above lamentation indicates that women are more interested in empowerment programs that enable them to play family providers roles. However, they can't afford the opportunity to emancipatory programs. Thus, the providers of adult education programs should do a continuous assessment to ascertain whether programs needed to empower women with work skills are implemented accordingly. And they are to ensure that the needs of the women are met by monitoring programs directed towards a national plan of helping women become economically active in their multi-cultural democratic societies.

Findings from the focus-group discussion buttress the revelations from the face-to-face interviews. When the researchers asked the group how the institution of ACET is empowering them, one member of the group said that; 
We are not given any form of skills training that can empower us for survival. What we need for livelihood is practical skills like business skills to conduct our own business; to be able to employ our friends; family members, and others in the community.

The respondent above buttresses that empowering rural women for survival requires training in practical livelihood skills. Women are eager to be productive to improve their socio-economic lives.

\subsection{Lack of Access to ACET Programs}

ACET is an essential tool to help women in rural areas develop socially and economically. Therefore, there is a need for them to have access to its programs. The Department of Higher Education and Training [9] aims to give opportunities to these womenfolk to access education and training. The Achievement of this objective can help bridge the skills and knowledge gap among most rural dwellers in general. As the study revealed, women find it challenging to access ACET programs because of financial difficulties. Many of the participants are unemployed and require financial support for their education. Fortunately, the government provides social grants for its citizens to help alleviate poverty [16]. However, this financial support is not sustainable enough as most rural women live below the poverty line. As they do not get this adequate financial support, many of them do not attend classes. A participant affirmed that;

I am a young person and unemployed. I depend on my grandmother for financial support. Without her support, I cannot attend classes because of transportation fares. The situation is very difficult because my grandmother is only depending on the old age grant she receives from the government which is not enough to care for the whole family.

Another participant had a similar concern:

I do not attend class every day and as a result, I do miss some of my lessons. The reason is that I do not have money to pay for my transport fares and I am not working.

Yet again, another participant mentioned that:

The problem that restricts me from attending classes regularly is hunger. Sometimes I do not have money to buy food to sustain me. As a result, I lose concentration in class because I am hungry. I do not like to attend classes because of this problem.

The responses above epitomize similar concerns and experiences of financial limitations. These limitations negatively affected women's education and training. Thus, it may result in many learners dropping out of their training and increasing skills shortfalls. The assertion is that rural women require financial support to pay for basic educational needs, for example, transportation. It can help them travel to ACET centers and benefit from their programs. Mandal [20] argues that access and opportunities to education are essential means to help rural women enjoy equal rights, equal status, and freedom from poverty and unemployment.

Unfortunately, most rural women do not have the financial muscle to support themselves, resulting in a lack of access to ACET programs. Also, most rural women are ignorant about ACET programs. Revelations from the focus-group discussion affirmed that most of the women do not know that ACET exists. One individual from the group said that;

We do not know about the ACET program until the educators come to our communities to look for learners to participate in ACET programs.

Because most women are ignorant of the existence of ACET, they might not be able to take the necessary steps towards their education and freedom from life's difficulties. The respondent response is an apparent indication of the failure of the providers of education and ACET to promote this provision for women. Thus, ACET must be appropriately advertised to attract women for advancement in their living conditions.

\subsection{Location of ACET Learning Centers}

A fundamental problem revealed by some of the respondents is seeing ACET learning centers located very distant places. It made it difficult for women to attend classes quickly. A participant, for instance, responded that her colleagues find it difficult to participate or attend classes because of the location of ACET centers. They have to travel long distances to attend classes. Most of the learners attend classes once a month because of the site and space. Thus, it suggests a need for adult education providers to locate the learning centers strategically to enable women to access the centers.

Also, since most participants are unemployed, having their learning centers closer will be to their advantage and encourage women to enroll in ACET programs in high numbers for community and national development. Furthermore, productive skills, including arts and crafts, leather works, carpentry, sewing, bead making, and painting [10], can help women engage in self-established projects rather than wait for others to employ them. The income generated from self-established projects can help women exercise their financial prowess to buy food, clothing, shelter, and acquire decent accommodation.

\subsection{Involvement of Women in the Development of ACET Curriculum}

An essential step towards solving a problem is knowing it. Hence, rural women can envisage the type of curriculum they need to solve their problems. For this reason, ACET providers should be in consultation with 
women to administer and design their learning curriculum. Indeed, some women supported this idea when interviewed. A participant said thus;

The education officials should conduct learner forums where we can be able to share our views on important issues concerning the curriculum or programs which seek to empower us for employment or engage in self-employment work.

Another participant also said:

We should be well informed of the programs we are registered for. This can help us to share our views on what we need to be trained in if what we are registered for is not appropriate for our training.

The responses indicated that rural women must be involved when designing their curriculum or programs of learning. Therefore, they can opt for their choice in the curriculum. Griggs et al. [14] affirm that women's voices are essential in development issues, which is why they need to have a say in curriculum design. The emphasis is to see rural women lead better lives through educational programs. Hence, they must design a learning program or curriculum that seeks to empower them for socio-economic freedom.

\section{Conclusion}

The researchers investigated the worth of Adult and Community Education and Training on women's lives using a qualitative exploratory design. The research revealed that most women in the countryside are helpless due to a lack of livelihood skills. The study emphasizes the need for the ACET curriculum to address the learning needs of women. For ACET to achieve this aim, its programs must be valuable to women's lives. However, participants' responses expose that most rural women failed to access ACET programs because of financial difficulties. The study expounds on why most of the participants do not have living wages to support themselves through education and training.

Additionally, ACET centers are situated in distant areas such that the women find it burdensome to attend classes. As a result, ACET classes have low attendance and patronage. Eventually, these might lead to school dropout or loss of hope in ACET programs. This means that rural women must be given the assistance to solve the problems they face, which is not including them in curriculum development. Interviews with the selected women revealed that they are interested in the curriculum or programs they have suggested in their education and training.

\section{Recommendation}

The study made recommendations based on the findings. It recommends that ACET programs be given serious attention, especially in satellite community learning centers, as the programs offered do not attend to the educational needs of the learners. Again, ACET needs to run programs to train learners in livelihood skills to share in the economy by actively engaging in self-employment work. To help rural women succeed in their education and training, adult education providers must involve the women before designing their learning programs.

\section{Limitation of the Study}

This qualitative study covers a more considerable number of participants. The researchers interviewed 20 participants (women), four female educators, and seven previous learners. In addition, four female learners were selected for a focus group discussion to make 35 participants in total. Given the small number sampled for the study $(n=35)$ and the use of only four community learning centers in the district, generalizing the results will be flawed. However, the results of the research could be similar to most rural communities nationally.

\section{Trustworthiness}

Quan-Baffour [26] posits that a study's trustworthiness tells of the magnitude of dependability of the instruments used to collect data. It also involves the step-by-step procedure the researchers used to amass data which speaks to the quality of data collected for the study. Therefore, to ensure trustworthiness, the interviews were recorded, of course, with participants' knowledge and permission. The researchers referred to these recordings to transcribe respondents' responses accurately. They also kept a ledger or field notes during field activities to ensure trustworthiness. By employing several different types of data collection techniques, the researchers were able to maintain the credibility and reliability of the study in their final report.

\section{REFERENCES}

[1] Baatjes, I., Chaka, T., Imagining community and education training centres, 2012 . Available at: http://www.dhet.gov.za/Adult\%20Education\%20and\%20T raining\%20Programmes/CETC\% (Accessed 2017/12/17).

[2] Bouchet, A., Ballouli, K., Bennett, G., Implementing a ticket sales force in college athletics: A decade of challenges. Sport Marketing Quarterly, vol. 20, no. 2, 2011. Retrieved from: http://www.sportmarketingassociation.co $\mathrm{m} /$ journal/.

[3] Cameron, R., The reconstruction and development programme. Journal of Theoretical Politics, vol. 8, no. 2, pp. 
283-294, 1996.

[4] Chamberlin, J., Schene, A.H., A working definition of empowerment. Psychiatric rehabilitation journal, vol. 20, no. 4, pp. 43-46, 1997.

[5] Collis, J., Hussey, R., Business research: A practical guide for undergraduate and postgraduate students, 3rd ed., Macmillan International Higher Education, 2013.

[6] Creswell, J., Mapping the field of mixed methods research. Journal of Mixed Methods Research, vol. 3, no. 2, pp. 95-108, 2009.

[7] Creswell, J. W., Controversies in mixed methods research. The Sage handbook of qualitative research, 4th ed., pp. 269-284, Sage Publications, 2011.

[8] Creswell JW., Creswell JD., Research design: Qualitative, quantitative, and mixed methods approaches, Sage Publications; 2017, Nov 27.

[9] Department of Higher Education and Training, White Paper for Post-School Education and Training, 2013. Available at: http://www.dhet.gov.za/SiteAssets/Latest $\% 20$ News/ White $\% 20$ paper $\% 20$ for $\% 20$

post-school\%20education $\% 20$ and $\% 20$ training.pdf (Accessed: 2018/06/15)

[10] Department of Higher Education and Training, National Policy on Curriculum Development and Implementation in Community Education and Training Colleges, 2017. Available at: http://www.dhet.gov.za/SiteAssets/Communi ty $\% 20$ College/National\%20policy\%20on $\% 20$ curriculum $\%$ 20development.pdf (Accessed: 2019/01/30).

[11] Dreze, J., Sen, A., India: Economic development and social opportunity. OUP Catalogue, 1999.

[12] Elliott, C. M., Global Empowerment of Women: Responses to globalization and politicized religions, 1st ed., Routledge, 2007.

[13] Gilchrist, A., The well-connected community: A networking approach to community development, 3rd ed., Policy Press, 2009.

[14] Griggs, D., Stafford-Smith, M., Gaffney, O., Rockström, J., Öhman, M. C., Shyamsundar, P., Noble, I., Policy: Sustainable development goals for people and planet. Nature, vol. 495, no. 7441, pp. 305-307, 2013.

[15] Horrell, M., Bantu education to 1968. South African Institute of Race Relations, 1969.

[16] Johnson, L. and Dichaba, M., The impact of social grants on rural women: perspectives from ABET practitioners. Mediterranean Journal of Social Sciences, 4(13), pp. 541-541, 2013.

[17] Kamando, A.N., Government-community partnership in the provision of education in Rural Tanzania (Doctoral dissertation, University of Glasgow), 2014.

[18] Kaur, A., Singh, N., Changing behaviour of society towards women empowerment. CLEAR International Journal of
Research in Commerce and Management, vol. 8, no. 2, pp. 20-40, 2017.

[19] Kirkaldy, A., Capturing the soul: The Vhavenda and the missionaries, 1870-1900, 1st ed., Protea, 2005.

[20] Lord, J., Hutchison, P., The process of empowerment: Implications for theory and practice. Canadian Journal of Community Mental Health, vol. 12, no. 1, pp. 5-22, 2009.

[21] Mandal, K. C., Concept and Types of Women Empowerment. In International Forum of Teaching and Studies, vol. 9, no. 2, pp. 17-30, 2013

[22] Marshall, B., Cardon, P., Poddar, A., Fontenot, R., Does sample size matter in qualitative research? A review of qualitative interviews in IS research. Journal of Computer Information Systems, vol. 54, no. 1, pp. 11-22, 2013.

[23] Moyo, C., Is Adult Basic Education the Answer to Rural Women's Poverty? Journal of Human Ecology, vol. 45, no. 2, pp. 111-118, 2014.

[24] Nachshen, J. S., Empowerment and families: Building bridges between parents and professionals, theory and research. Journal on Developmental Disabilities, vol. 11, no. 1, pp. 67-76, 2005.

[25] Nichols, G., Tacon, R., Muir, A., Sports clubs' volunteers: Bonding in or bridging out? Sociology, vol. 47, no. 2, pp. 350-367, 2013. http://0-dx.doi.org.oasis.unisa.ac.za/10.117 $7 / 0038038512441278$.

[26] O'Faircheallaigh, C., Public participation and environmental impact assessment: Purposes, implications, and lessons for public policy making. Environmental impact assessment review, vol. 30, no. 1, pp. 19-27, 2010.

[27] Quan-Baffour, K. P., The liberative power of education: Adult basic education as empowerment tool for rural women in Taung. Studies of Tribes and Tribals, vol. 10, no. 2, pp. 91-97, 2012.

[28] Quan-Baffour, K. P., Youth empowerment: A strategy to mitigate vulnerability to human trafficking in Ghana. Participatory Educational Research vol. 2, no. 1, pp. 25-33, 2015.

[29] Rappaport, J., Terms of empowerment/exemplars of prevention: Toward a theory for community psychology. American journal of community psychology, vol. 15, no. 2, pp. 121-148, 1987.

[30] Singh, A., Non Governmental Organizations interventions and women empowerment, 2015. http://hdl.handle.net/106 $03 / 203622$.

[31] Troup, F., Forbidden pastures: Education under apartheid. London: International Defence and Aid Fund, 1976.

[32] Welman, C., Kruger, F., Mitchell, B., Research Methodology 3rd ed., Cape Town: Oxford University Press Southern Africa (Pty) Ltd, pp. 165-167, 2005.

[33] Zikmund, W.G., Babin, B.J., Carr, J.C., Griffin, M., Business Research Methods, 7th ed., South-Western: John Wiley and Sons Inc., 2003. 